\title{
Implikasi Hukum Penerapan Pasal 91 Ayat (1) Undang-Undang Nomor 28 Tahun 2009 Terhadap KonstelasiPemindahan Hak
}

\author{
Nia Kurniati \\ Fakultas Hukum Universitas Padjadjaran \\ nia.kurniati@unpad.ac.id
}

\begin{abstract}
Tax payment for land and building rights transfer is an obligation which has to be performed by the party who gains its rights through certain transactions. According to Article 91(1) of Regional Tax and Retribution Act No.28 Year of 2009, civil law notary may only sign the deed of transfer of land and building rights after the aforementioned party submit its confirmation of said tax payment. Such provision shows discrepancy with tax law in which imposed tax should be based ontaatbestand of the taxpayer. This study aimed to uncover legal principle underlies the establishment of imposed tax from the transfer of land and building rights. This study uses normative approach which employ qualitative method in its analysis. Tax for land and building rights transfer whichimposed before the establishment of taatbestand is based on the principle of "tax will be imposed at the closest moment of rights be gained by the taxpayer". The provision setforth in Article 91(1) has to be understood along with Article 90(1)(a) of said Act. The ratio legis of Article 91(1) of said Act is to avoid tax evasion on the tax for land and building rights transfer.
\end{abstract}

Keywords: transaction, rights transfer, payable tax

\begin{abstract}
Abstrak
Pembayaran pajak BPHTB merupakan kewajiban pajak yang harus dipenuhi oleh pihak yang memperoleh hak atas tanah melalui jual beli. Ditentukan dalam UU 28 Tahun 2009 Pasal 91 ayat (1), bahwa "PPAT/Notaris hanya dapat menandatangani akta pemindahan Hak atas Tanah dan/atau Bangunan setelah Wajib Pajak menyerahkan bukti pembayaran pajak". Bunyi pasal ini menunjukan pertentangan dengan konstelasi pajak, yang secara teoritik berpedoman pada taatbestand sebagai dasar menentukan saat timbulnya utang pajak. Penelitan ini bertujuan menemukan asas hukum yang mendasari fiscus mengenakan pajak atas pemindahan hak melalui jual beli. Penelitian ini menggunakan metode Yuridis Normatif dengan analisis data secara Yuridis Kualitatif. Hasil penelitian menunjukkan bahwa Pengenaan kewajiban pajak kepada wajib pajak BPHTB, sebelum dipenuhinya taatbestand dilandasai oleh asas hukum "pajak dikenakan pada saat yang paling dekat dengan detik diperolehnya hak". Pengenaan Pasal 91 Ayat (1) UU No.28 Tahun 2009 terhadap pemindahan hak atas tanah, harus dilihat ke dalam titik tautnya dengan Pasal 90 ayat (1) huruf a UU No.28 Tahun 2009. Kesimpulan : Ratio legis penerapan Pasal 91 ayat (1) untuk menghindarkan pengingkaran penunaian kewajiban pajak BPHTB oleh wajib pajak.
\end{abstract}

Kata kunci: jual beli, pemindahan hak, timbulnya utang pajak. 


\section{Pendahuluan}

Dalam pemindahan hak melalui cara peralihan hak (jual beli), perbuatan hukum tersebut dikehendaki akibatnya oleh pihakpihak yang bersangkutan, atau dengan kata lain ada kesengajaan untuk mengalihkan hak atas tanah oleh pemegang haknya kepada pihak lain. Cara pemindahan hak atas tanah melalui peralihan hak jual beli, dimaknai sebagai "suatu perjanjian bertimbal balik dalam mana pihak yang satu (penjual) berjanji untuk menyerahkan hak milik atas suatu barang sedangkan pihak yang lain (pembeli) berjanji untuk membayar harga yang terdiri atas sejumlah uang sebagai imbalan dari perolehan hak milik tersebut" (Subekti, 1982 : 13).

Objek perjanjian jual beli berupa benda tidak bergerak yaitu tanah atau hak atas tanah, hukum tanah nasional telah memberikan ketentuan hukum mengenai pemindahan hak dan mengenai pemberian surat tanda bukti hak kepemilikannya, artinya dengan dilakukannya perbuatan hukum jual beli,hak atas tanah yang bersangkutan berpindah kepada pihak lain (Boedi Harsono, 2003 :
333). Pelaksanaan pemindahan hak melalui cara jual beli dilakukan oleh para pihak di hadapat Pejabat Pembuat Akta Tanah (PPAT) yang bertugas membuat aktanya. Akta Jual Beli yang dibuat oleh PPAT membuktikan bahwa benar-benar telah dilakukan perbuatan hukum jual beli. Oleh karena perbuatan hukum yang dilakukan merupakan perbuatan hukum pemindahan hak, maka Akta PPAT secara implisit membuktikan bahwa penerima hak telah menjadi pemegang haknya yang baru. Akta Jual Beli (AJB) merupakan bukti sah bahwa hak atas tanah dan/bangunan sudah beralih kepada pihak lain (pembeli), dengan kata lain pembeli memperoleh hak atas tanah melalui jual beli, demikian menurut Pasal 37 Peraturan Pemerintah (PP) Nomor 24 Tahun 1997 Tentang Pendaftaran Tanah.

Perolehan hak atas tanah dan atau bangunan oleh individu atau badan menimbulkan utang pajak bagi pihak penerima hak atau yang memperoleh hak, atau dengan kata lain perolehan hak atas tanah merupakan objek pajak yang dikenal dengan sebutan "Bea Perolehan Hak 
atas Tanah dan Bangunan" (BPHTB), demikian menurut ketentuan Undang-Undang No.28 Tahun 2009 tentang Pajak dan Retribusi Daerah Pasal 85 ayat (1). Pemungutan pajak BPHTB dalam sistem perpajakan Indonesia merupakan perwujudan, dan peran serta wajib pajak untuk pembiayaan daerah pada khususnya dan pembangunan nasional pada umumnya. Tanggung jawab mengenai penunaian kewajiban pajak ini berada pada masyarakat wajib pajak itu sendiri. Wajib pajak diberi kepercayaan untuk menghitung dan menyetor sendiri pajak nya yang terutang.

Merujuk pada tatanan hukum pajak menurut "ajaran materil" bahwa Hutang pajak adalah hutang yang timbul secara khusus, yaitu timbul karena undang-undang. Menurut “ajaran materiil" untuk timbulnya hutang pajak tidak diperlukan Surat Ketetapan Pajak oleh Fiskus atau pemungut pajak. Artinya hutang pajak timbul jika Undang-Undang yang menjadi dasar pemungutannya telah ada, dan syarat subjektif serta objektifnya telah terpenuhi (Tulis . Meliala, 1991 : 7). Dalam hal ini Pajak BPHTB terutang timbul atau dikenakan terhadap wajib pajak adalah apabila telah dipenuhi taatbestand-nya atau terdapat alasan pengenaan pajak yaitu perbuatan hukum pemindahan hak oleh satu pihak yang mengakibatkan perolehan hak oleh pihak lain. Ajaran materil ini diadopsi oleh hukum pajak positif Indonesia, sehingga saat terjadinya utang pajak tidaklah selalu dinyatakan dengan terang di dalam undang-undangnya melainkan yang dipentingkan adalah terpenuhinya taatbestand (perbuatan) dan barulah kemudian diperhatikan subjek pajaknya yang bersangkutan (R. Santoso Brotodihardjo, 2003 : 116117).

Saat terutangnya Bea Perolehan Hak atas Tanah dan Bangunan ditetapkan untuk jual beli adalah sejak dibuat dan ditandatanganinya Akta oleh Pejabat Pembuat Akta Tanah, demikian menurut Pasal 90 (1) huruf a Undang-Undang No.28 Tahun 2009. Pada sisi lain terdapat ketentuan hukum yang menyebutkan, “penandatanganan Akta oleh PPAT, 
didahului oleh kewajiban pajak berkewajiban membayar pajak terutang dengan cara dibayar sendiri oleh wajib pajak", demikian menurut Pasal 6 ayat (1) Peraturan Pemerintah No. 91 Tahun 2010 tentang Tata Cara Pemberian dan Pemanfaatan Insentif Pemungutan Pajak Daerah dan Retribusi Daerah. Kewajiban pajak ini ditetapkan demikian karena Undang-Undang No.28 Tahun 2009 Pasal 91 ayat (1) menyebutkan, bahwa "Pejabat Pembuat Akta Tanah/Notaris hanya dapat menandatangani akta pemindahan Hak atas Tanah dan/atau Bangunan setelah Wajib Pajak menyerahkan bukti pembayaran pajak".

Apabila memperhatikan bunyi Pasal 91 ayat (1) UU No.28 Tahun 2009 yang menyatakan bahwa "Pejabat Pembuat Akta Tanah/Notaris hanya dapat menandatangani Akta pemindahan Hak atas Tanah dan/atau Bangunan setelah Wajib Pajak menyerahkan bukti pembayaran pajak", ini berarti penandatanganan Akta didahului penunaian kewajiban pembayaran pajak BPHTB oleh wajib pajaknya; padahal utang pajaknya belum timbul. Kenyataan ini kiranya tidak seiring dengan prinsip “ajaran materiil" yang menyebutkan bahwa “timbulnya utang pajak" yaitu ketika telah dipenuhinya taatbestand (syaratnya); maka ini menimbulkan kerancuan dan berimplikasi pada penetapan saat kapan timbulnya hutang pajak dan saat kapan terjadinya pemindahan hak atas tanah dari satu pihak kepada pihak lainnya.

Sehubungan dengan uraian pada latar belakang tersebut terjadi kesenjangan hukum, yaitu pelaksanaan kewajiban pajak oleh wajib pajak BPHTB mendahului dipenuhinya taatbestand. Dalam hal ini utang pajak sudah harus dipenuhi, padalah peralihan hak atas tanah tersebut belum terjadi. Tujuan penelitian ini adalah menemukan asas hukum yang mendasari fiscus mengenakan pajak BPHTB secara bertentangan secara teoretik dengan konstelasi pajak.Hal ini menjadi alasan pentingnya penelitian ini dengan menggunakan pendekatan secara yuridis normatif dengan 
metode analisis data secara yuridis kualitatif.

\section{Hasil Pembahasan}

Pemindahan Hak atas Tanah Dalam Perspektif UUPA, Hukum Adat dan KUHPerdata

Pemindahan hak atas tanah yang dilakukan melalui cara peralihan haktelah mendapat pengaturannya dalam hukum tanah nasional demikian pula mengenai surat tanda bukti pemilikannya, yaitu terdapat dalam Pasal 23 a Peraturan Pemerintah No.24 Tahun 1997 tentang Pendaftaran Tanah. Salah satu cara peralihan hak dilakukan melalui jual beli disebut dalam Peraturan Pemerintah No.37 Tahun 1998 Pasal 2 ayat (2) huruf a yang telah diganti oleh Peraturan Pemerintah No.24 Tahun 2016 tentang Perubahan atas Peraturan Pemerintah No.37 Tahun 1998 tentang Peraturan Jabatan Pejabat Pembuat Akta Tanah.

Jual beli merupakan perbuatan hukum untuk sengaja mengalihkan hak kepada pihak lain, dan jual beli merupakan perbuatan hukum pemindahan hak yang bersifat “tunai” (Boedi Harsono, 2003 : 333).
Jual beli dilakukan oleh para pihak yaitu penjual dan pembeli di hadapan Pejabat Pembuat Akta Tanah (PPAT) yang bertugas membuat aktanya, yaitu Akta Jual Beli (AJB). Pengertian otentik mengenai PPAT dan Akta PPAT dinyatakan dalam Pasal 1 Peraturan Pemerintah No.37 Tahun 1998 menyebutkan, bahwa PPAT "adalah pejabat umum yang diberi kewenangan untuk membuat akta-akta otentik mengenai perbuatan hukum tertentu mengenai hak atas tanah", sedangkan produk hukum PPAT adalah Akta PPAT yaitu akta yang dibuat oleh PPAT sebagai bukti telah dilaksanakannya perbuatan hukum tertentu mengenai hak atas tanah. Dengan dilakukannya perbuatan hukum jual beli dihadapan PPAT, telah dipenuhi syarat "terang" dan penandatanganan Akta oleh para pihak secara "nyata" menunjukkan perbuatan hukum jual beli itu benarbenar dilakukan. Unsur tunai, terang dan riil pada jual beli tersebut telah terpenuhi adalah sesuai pula dengan sifat jual beli menurut hukum adat dimana sahnya jual beli harus memenuhi 3 unsur yaitu "tunai, riil atau nyata dan terang" (Soerjono 
Soekanto, 2003 : 189; Bushar Muhamad, 1994 : 47).

Akta PPAT membuktikan bahwa benar-benar telah dilakukan perbuatan hukum yang bersangkutan dan oleh karena perbuatan hukum yang dilakukan merupakan perbuatan hukum pemindahan hak, maka akta PPAT secara implisit juga membuktikan bahwa pembeli sebagai penerima hak sudah menjadi pemegang hak yang baru (Boedi Harsono, 2003 : 334). Dengan demikian saat kapan terjadinya peralihan hak atas tanah melalui jual beli, adalah sejak ditandatanganinya akta oleh PPAT.

Unsur-unsur pokok (esensialia) perjanjian jual beli adalah "barang dan harga", dan kesepakatan tentang barang dan harga di antara penjual dan pembeli didasari asas “konsensualisme”. Hukum perjanjian dalam KUHPerdata menganut asas konsensualisme, hal ini disimpulkan dari Pasal 1320 KUHPerdata yang menyebut unsur-unsur sahnya perjanjian yaitu (i) Sepakat, (ii). Cakap, (iii) Objek tertentu, dan (iv) Causa yang halal. Berdasarkan asas"konsensualisme", perjanjian jual beli itu sudah dilahirkan pada saat tercapainya "kesepakatan" mengenai "barang dan harga". Begitu kedua belah pihak penjual dan pembeli setuju akan barang dan harga, maka lahirlah perjanjian jual beli secara sah (Subekti, 1982 : 14). Sifat "konsensuil" daripada Jual beli ditegaskan dalam Pasal 1458 KUHPerdata yang berbunyi "Jual beli dianggap sudah terjadi antara kedua belah pihak, seketika setelah mereka mencapai sepakat tentang barang dan harga, meskipun barang itu belum diserahkan maupun harganya belum dibayar".

Kesepakatan merupakan persesuaian kehendak, dan kehendak ini harus dinyatakan, dan yang menjadi alat ukur tercapainya persesuaian kehendak adalah pernyataan-pernyataan yang telah dilakukan oleh kedua belah pihak.Ini merupakan suatu tuntutan kepastian hukum yang merupakan satu sendi yang mutlak dari suatu tata hukum yang baik. Dalam hal ini bahwa orang yang hidup dalam masyarakat yang teratur harus dapat dipegang perkataan atau ucapannya,dan pernyataan yang boleh dipegang 
sebagai dasar kesepakatan adalah pernyataan yang secara objektif dapat dipercaya. Suatu pernyataan yang dilakukan secara tidak sungguh-sungguh atau mengandung suatu kekhilafan atau kekeliruan tidak boleh dijadikan dasar kesepakatan.

Oleh karenanya persesuaian kehendak atau konsensus diukur dengan pernyataan-pernyataan yang secara bertimbal balik telah dikeluarkan. Pernyataan timbal balik dari kedua belah pihak merupakan sumber untuk menetapkan hak dan kewajiban bertimbal balik diantara kedua belah pihak penjual dan pembeli. Dengan hanya menyebut "sepakat" saja tanpa dituntutnya suatu bentuk cara (formalitas) tertentu secara tertulis, pemberian tanda bayar atau panjer, asal sudah sepakat mengikatlah perjanjian itu dan perjanjian berlaku sebagai undang-undang bagi mereka yang membuatnya (Subekti, 1982 : 16).

Sehubungan dengan yang menjadi objek perjanjian jual beli adalah benda tidak bergerak (hak atas tanah), maka setelah dilakukan peralihan hak dengan Akta PPAT masih diperlukan tindakan Balik Nama di Kantor Pertanahan untuk memperoleh surat bukti yang lebih kuat dan pembuktian pemindahan haknya harus didaftarkan pada Kantor Pertanahan Kabupaten/Kota untuk dicatat pada Buku Tanah dan sertifikatnya. Dengan dicatatnya pemindahan hak tersebut pada buku tanah dan sertifikat haknya, telah diperoleh surat tanda bukti yang kuat,pencatatan ini selain memindahkan haknya juga pihak ketigapun dianggap mengetahui bahwa penerima hak adalah pemegang haknya yang baru.

\section{Pajak, Timbulnya Utang Pajak, dan Peralihan Hak atas Tanah}

Peralihan hak atas tanah merupakan salah satu cara pemindahan hak, peralihan hak atas tanah yang dilakukan oleh seseorang atau badan mempunyai keterkaitan yang erat dengan hal perpajakan. Peralihan hak atas tanah adalah perbuatan hukum pemindahan hak atas tanah yang dilakukan dengan sengaja supaya hak tersebut terlepas dari pemegangnya semula dan menjadi hak pihak lain (K Wantjik Saleh, 1977 : 15-18). Salah satu 
perbuatan hukum pemindahan hak atas tanah yaitu melalui Jual Beli, dan pembuktian bahwa hak atas tanah tersebut dialihkan, maka harus dibuktikan dengan suatu akta yang dibuat oleh dan dihadapan PPAT yaitu akta jual beli yang kemudian akan dijadikan dasar pendaftaran perubahan data pendaftaran tanah sebagaimana dimaksud dalam ketentuan Pasal 95 ayat 1 huruf a Peraturan Menteri Agraria/Kepala Badan Pertanahan Nasional Nomor 3 Tahun 1997. Akta Jual Beli yang dibuat dihadapan PPAT tersebut bertujuan untuk memberikan kepastian hukum kepada pemegang hak atas suatu bidang tanah (pembeli tanah).

Akta PPAT dalam pembuatannya harus dihadiri oleh 2 orang saksi. Kehadiran 2 orang saksi ini merupakan aspek formal dalam pembuatan akta PPAT. Jika ketentuan tersebut dilanggar akan membuat kedudukan akta menjadi hanya sebatas akta di bawah tangan saja. Aspek formal tersebut harus dipenuhi oleh PPAT dalam pembuatan akta karena merupakan bagian dari kewajiban PPAT dalam pelaksanaan pembuatan akta sebagaimana disebutkan dalam Peraturan Jabatan PPAT. Kedudukan saksi sebagai bagian dari aspek formal akta PPAT adalah sebagai sosok yang dianggap mengetahui tentang peristiwa atau kejadian yang dialaminya sendiri, yaitu pembuatan akta PPAT. Pada posisi tersebut saksi menyaksikan bahwa telah terjadi pembuatan akta PPAT berdasarkan kehendak para pihak, menyaksikan bahwa akta telah dibacakan oleh PPAT dihadapan para pihak dan akta PPAT telah ditandangani oleh para pihak, saksisaksi dan PPAT atau dengan kata lain bahwa saksi-saksi tersebut menyaksikan bahwa segala aspek formal dalam pembuatan akta telah dipenuhi oleh PPAT yang bersangkutan, sehingga aktanya memenuhi syarat sebagai akta otentik (Hatta Isnaini Wahyu Utomo dan Hendry Dwicahyo Wanda (2017). Prinsip Kehati-Hatian Pejabat Pembuat Akta Tanah dalam Peralihan Tanah yang Belum Bersertifikat, Jurnal Hukum Ius Quia Iustum No. 3 Vol. 24 Juli : 476). 
Secara teoretik perbuatan atau peristiwa hukum, pada saat, sejak tanggal dibuat dan ditandatangani akta, menimbulkan lahirnya utang pajak atau dengan kata lain timbulnya utang pajak harus didahului atau diawali dengan perbuatan perolehan hak. Perolehan hak atas tanah dimaksud merupakan perbuatan atau peristiwa hukum yang mengakibatkan diperolehnya hak atas tanah dan/atau bangunan oleh orang pribadi atau Badan.

Sehubungan dengan ini, penting untuk memahami arti pajak itu sendiri, dan untuk memahami arti pajak secara teoretik dapat ditinjau melalui pendekatan dariberbagai segi disiplin ilmu, seperti dari segi hukum, segi ekonomi, segi sosiologi, segi keuangan, segi pembangunan, dan segi administratif. Di dalam penulisan ini, Pajak dilihat dari segi hukum,seperti didefinisikan oleh Rochmat Soemitro bahwa pajak,"adalah perikatan yang timbul karena undang-undang, yang mewajibkan seseorang yang memenuhi syarat (taatbestand) yang ditentukan dalam undang-undang, untuk membayar sejumlah uang tertentu kepada negara, yang dapat dipaksakan, dengan tiada mendapat imbalan yang secara langsung dapat ditunjuk, yang digunakan untuk membiayai pengeluaran-pengeluaran negara. Dari pengertian pajak tersebut dapat ditarik unsur-unsur pajak, yaitu (i) pajak merupakan hubungan perikatan, (ii) pajak hanya dapat diadakan dengan undangundang, (iii) terdapat pembayaran sejumlah uang, (iv) dapat dipaksakan, (v) tanpa imbalan secara langsung yang dapat ditunjuk.

Pendekatan pajak dari segi hukum melihat pada segi hubungan hukumnya sehingga pajak dilihat dari segi hak dan kewajiban, yaitu dalam hal ini siapa berhak memungut pajak, apa kewajiban pemungut pajak terhadap wajib pajak, siapa wajib pajak, apa hak dan kewajiban wajib pajak terhadap fiskus, kapan hutang pajak itu timbul, bagaimana cara pembayaran pajak, dan apa sanksi-sanksi yang terdapat dalam hukum pajak, apa arti sanksi administratif, dan apa sanksi arti pidana (Rochmat Soemitro, 1990 : 51). Oleh Rochmat Soemitro disebutkan pula bahwa "pajak 
adalah peralihan kekayaan dari pihak rakyat kepada negara, dari sektor privat kepada sektor publik, dari penduduk kepada masyarakat untuk membiayai pengeluaran rutin dan suprlusnya digunakan untuk public saving yang merupakan sumber utama untuk membiayai public investment" (Santoso, 2003 : 6).

Berdasarkan pengertian tersebut, Rochmat Soemitro menekankan pajak sebagai suatu perikatan, suatu hubungan hukum antara negara dengan rakyat, yang timbul karena undang-undang, yang menyebabkan timbulnya kewajiban rakyat untuk menyerahkan sejumlah uang tertentu kepada kas negara, atas penyerahan uang tersebut negara mempunyai kekuatan untuk memaksa namun tidak ada kontraprestasi dari negara yang dapat dinikmati oleh pembayar pajak, dan uang pajak tersebut oleh negara dipergunakan untuk penyelenggaraan pemerintahan atau untuk mencapai suatu tujuan tertentu yang dikehendaki negara, surplus daripada pajak untuk public saving. Pendekatan dari segi hukum menegaskan, bahwa pajak harus dipungut dengan undang-undang untuk menciptakan kepastian hukum baik bagi pemungut pajak maupun bagi pembayar pajak (Dewi Kania, Zainal Mutaqin, 2015 : 3), ini sesuai dengan bunyi Pasal 23 A UndangUndang Dasar 1945, yang menyebutkan "pajak dan pungutan lain yang bersifat memaksa untuk keperluan negara diatur dengan undang-undang”.

Memperhatikan pengertian pajak dari segi hukum menunjukan kewenangan negara memungut pajak, dan hal pelaksanaan wewenang tersebut ditujukan semata-mata untuk mengisi kas negara/daerah ataupun untuk tujuan lain yang hendak dicapai yang tidak langsung berkaitan dengan pengisian kas negara. Pelaksanaan kewenangan Negara untuk memungut pajak dari wajib pajak, hanya dapat terlaksana jika telah dipenuhi taatbestand-nya (syaratnya). Dalam hal ini, wajib telah memenuhi syarat-syarat objektif dan syarat subjektif.

Terpenuhinya syarat objektif, artinya telah memenuhi taatbestand yang ditentukan oleh undangundang, yaitu "perbuatan hukum peralihan hak atas tanah". Hak atas 
Tanah dan/atau Bangunan dimaksud adalah hak atas tanah, termasuk hak pengelolaan, beserta bangunan di atasnya, sebagaimana dimaksud dalam undang-undang di bidang pertanahan. Berdasarkan Pasal 16 ayat (1) Undang-Undang Nomor 5 Tahun 1960 tentang Peraturan Dasar Pokok-Pokok Agraria, hak-hak atas tanah tersebut meliputi (i) Hak Milik, (ii) Hak Guna Usaha, (iii) Hak Guna Bangunan, (iv) Hak Pakai. Semula sebelum terpenuhi taatbestand-nya ia adalah subjek pajak, yaitu "orang atau badan yang memenuhi syarat subjektif, selanjutnya subjek pajak akan menjadi wajib pajak jika ia sekaligus juga memenuhi syaratsyarat objektif (Rochmat Soemitro, $1990: 62)$.

Syarat subjektif yang harus dipenuhi dalam peralihan hak atas tanah, yaitu yang bersangkutan tidak terhalang untuk mempunyai hak atas tanah menurut Undang-Undang No.5 Tahun 1960, yaitu individu warganegara Indonesia (WNI) atau badan yang berkedudukan di Indonesia dan didirikan menurut hukum Indonesia. Syarat objektifnya yaitu perbuatanhukum peralihan hak atas tanah yang menyebabkan perolehan hak atas tanah oleh penerima hak.

Pengenaan pajak kepada wajib pajak sehubungan pemindahan hak melalui perbuatan hukum peralihan hak atas tanah oleh individu atau badan kepada pihak lain yangdibuktikan dengan akta PPAT mengakibatkan individu atau badan yang bersangkutan menjadi pemegang hak baru atas objek yang bersangkutan (hak atas tanah), dan akibat hukumnya atas objek tersebut melekat kewajiban pajak objektif. Kewajiban pajak objektif dimaksud adalah kewajiban pajak yang melekat pada suatu objek seperti ditentukan oleh undang-undang, dan kewajiban pajak objektif hanya timbul saat dipenuhinya taatbestand.

Pengenaan pajak terhadap pemegang hak baru menimbulkan hutang pajak yang harus dipenuhinya. Hutang Pajak yang dikenakan terhadap pemegang hak baru ditentukan dalam UndangUndang No.28 Tahun 2009, yaitu pajak Bea Perolehan Hak atas Tanah dan Bangunan (BPHTB). Pajak BPHTB ini termasuk ke dalam 
golongan pajak objektif yang dipungut ketika terdapat peristiwa atau perbuatan. Mengenai saat kapan utang pajak BPHTB ini timbul telah ditentukan dalam Undang-Undang No.28 Tahun 2009 Pasal 90 ayat (1), yaitu sejak tanggal dibuat dan ditandatanganinya akta jual beli oleh PPAT.

Dari uraian tersebut di atas, Undang-Undang No.28 Tahun 2009 telah mengadopsi prinsip ajaran materiil terhadap penentuan penunaian pajak terutang yang harus dibayar oleh wajib pajak BPHTB. Sesuai dengan prinsip dalam Ajaran Hutang Pajak Materiil, bahwa utang pajak timbulnya bukan karena ketetapan oleh fiskus melainkan karena undang-undang, sehingga untuk timbulnya hutang pajak BPHTB tidak diperlukan Surat Ketetapan Pajak (SKP) oleh fiskus. Menurut "ajaran materiil" SKP tidak menimbulkan hutang pajak sebab hutang pajak timbul karena UndangUndang yaitu pada saat dipenuhinya taatbestand, sehingga SKP hanya mempunyai fungsi "memberitahukan besarnya pajak terutang dan menetapkan besarnya utang pajak sehingga sifatnya hanya declaratoir.

Ratio LegisPenerapan Pasal 91 ayat (1) UU No.28 Tahun 2009 dan Implikasi Hukum Terhadap KonstelasiPemindahan Hak

Secara teoretik "perbuatan" merupakan salah satu alasan pengenaan pajak kepada subjek pajak yang melakukan "perbuatan hukum peralihan hak" (tanah). Menurut konstelasi Pajak, pada saat sejak tanggal dibuat dan ditandatangani akta oleh PPAT/Notaris menjadi dasar timbulnya utang pajak, yaitu pajak Bea Perolehan Hak atas Tanah dan Bangunan (BPHTB). Dalam hal ini dimaksudkan, bahwa utang pajak timbul harus didahului diawali dengan perbuatan perolehan hak (telah dipenuhi taatbestand-nya). Bukan berarti pajak BPHTB dibayar dulu kemudian hak diperoleh. Namun ditetapkan dalam Pasal 91 ayat (1) UU No.28 Tahun 2009 bahwa "Pejabat Pembuat Akta Tanah/Notaris hanya dapat menandatangani akta pemindahan Hak atas Tanah dan/atau Bangunan setelah Wajib Pajak menyerahkan 
bukti pembayaran pajak". Pejabat Pembuat Akta Tanah tidak dapat meligitimasi perbuatan hukum pemindahan hak tanpa diselesaikannya pembayaran pajak BPHTB. Pejabat Pembuat Akta Tanah/Notaris yang melanggar ketentuan dalam Pasal 91 ayat (1) dikenakan sanksi administratif berupa denda sebesar Rp7.500.000,00 (tujuh juta lima ratus ribu rupiah) untuk setiap pelanggaran, demikian menurut ketentuan Pasal 93 Ayat (1) UU No.28 Tahun 2009. Atas pelanggaran yang dilakukan oleh PPAT, dikenakan sanksi yang diatur dalam Peraturan Jabatan PPAT. Di dalam Peraturan Jabatan PPAT, terdapat pengaturan mengenai pemberhentian, pelanggaran ringan, serta pelanggaran berat yang dilarang dilakukan oleh seorang PPAT. Dengan demikian terdapat tuntutan kehati-hatian daripada PPAT agar terhindar dari pusaran permasalahan hukum.

Di dalam sistem perpajakan Indonesia, sanksi menjadi penting karena telah dipilih Self Asssesment System dalam pemungutan
pajak.Pemungutan pajak Bea Perolehan Hak atas Tanah dan Bangunan (BPHTB) merupakan pajak terutang yang harus dibayar oleh pihak yang menerima perolehan hak atas tanah. Pemungutan dan atau pembayaran BPHTB oleh wajib pajak merupakan hal yang sangat penting dalam perolehan hak atas tanah,karena bunyi Pasal 91 Ayat (1) UU No.28 Tahun 2009 melarang Notaris/PPAT menandatangani Akta pemindahan hak sebelum dilakukan pembayaran pajak oleh Wajib Pajak BPHTBsebagaimana mestinya sesuai peraturan perundang-undangan yang berlaku.

Peraturan Pemerintah No. 91 Tahun 2010 tentang Jenis Pajak Daerah Yang Dipungut Berdasarkan Penetapan Kepala Daerah atau Dibayar Sendiri oleh Wajib Pajak, merupakan Peraturan Pelaksanaan dari UU No.28 Tahun 2009 menyebutkan dalam Pasal 4, bahwa BPHTB merupakan jenis pajak Kabupaten/Kota yang pemungutannya denga cara "dibayar sendiri oleh Wajib Pajak". Pemungutan BPHTB dilakukan berdasarkan prinsip menghitung dan 
membayar sendiri pajak terutang (Self Assesment System). Ciri pemungutan pajak dengan cara Self Assesment System yaitu (H. Mustaqiem, 2008 : 93): (i) wewenang menghitung dan menentukan jumlah hutang pajak ada pada pihak wajib pajak dan hasilnya dituangkan dalam Surat Pemberitahuan Pajak; (ii) Wajib pajak harus aktif melaporkan, membayarkan atau menyetorkan jumlah pajak yang terutang ke Ditjen Pajak; (iii) Pemerintah sebagai pihak pemungut pajak tidak ikut campur dalam menghitung dan menentukan jumlah pajak, tetapi hanya bertugas melaksanakan pengawasan.

Dalam Self Assesment System, inisiatif untuk memenuhi kewajiban pajak terutang berada pada wajib pajak itu sendiri.Wajib pajak diberi kewenangan untuk menghitung, menyetor, dan melaporkan sendiri pajak terutang, sedangkan fiskus hanya mengawasi saja. Dengan demikian diperlukan adanya kesadaran dan kejujuran yang tinggi bagi masyarakat wajib pajak untuk melaksanakan kewajibannya dalam membayar pajak. Disamping itu diperlukan peran dari petugas pajak dalam melakukan pengawasan terhadap kepatuhan wajib pajak dalam membayar pajak, demikian pula dalam penerimaan dan pengelolaannya.

Dalam rangka pengawasan terhadap kepatuhan wajib pajak, sekaligus efektifitas dalam membayar pajak BPHTB dilakukan proses validasi oleh kantor pelayanan pajak daerah. Dalam proses validasi inilah petugas akan meneliti beberapa hal diantaranya tentang: kesesuaian obyek pajak dengan Nomor Obyek Pajak (NOP) atas tanah dan bangunan yang bersangkutan, kesesuaian antara subyek pajaknya, kesesuaian nilai transaksi yang digunakan sebagai dasar pengenaan pajak BPHTB. Dengan demikian dalam sistem pemungutan BPHTB tidak sepenuhnya menganut Self Assessment System (R. Murjiyanto, Samaun (2016), Menetapkan Pilihan Nilai Jual Obyek Pajak Bumi dan Bangungan sebagai Dasar Penghitungan Bea Perolehan Hak atas Tanah dan Bangunan, Jurnal Hukum Ius Quia Iustum No. 1 Vol. 
23 Januari :149).Dikemukakan dalam Pasal 6 ayat (3) peraturan ini, bahwa Pemungutan Pajak terutang dengan cara "dibayar sendiri oleh Wajib Pajak" merupakan pembayaran Pajak terutang oleh Wajib Pajak dengan menggunakan (i) Surat Pemberitahuan Pajak Daerah; (ii) Surat Ketetapan Pajak Daerah Kurang Bayar; dan/atau (iii) Surat Ketetapan Pajak Daerah Kurang Bayar Tambahan.Di dalam Penjelasan pasal ini menyebutkan bahwa,Wajib Pajak yang memenuhi kewajibannya dengan cara membayar sendiri, diwajibkan melaporkan Pajak yang terutang dengan menggunakan Surat Pemberitahuan Pajak Daerah (SPTPD). Surat Pemberitahuan Pajak Daerah, adalah surat yang oleh Wajib Pajak digunakan untuk melaporkan perhitungan dan/atau pembayaran pajak, objek pajak dan/atau bukan objek pajak, dan/atau harta dan kewajiban sesuai dengan ketentuan peraturan perundangundangan perpajakan daerah.

Untuk memenuhi ketentuan Undang-undang Nomor 28 Tahun 2009 tentang Pajak Daerah dan
Retribusi Daerah, masing-masing Pemerintah Kota/Kabupaten menetapkan Peraturan Daerah masing-masing tentang Bea Perolehan Hak Atas Tanah Dan Bangunan. Sebagai contoh di Kota Bandung, Pajak BPHTB diatur dalam Peraturan Daerah Kota Bandung Nomor 02 Tahun 2011 Tentang Bea Perolehan Hak Atas Tanah Dan Bangunan, dan untuk melaksanakan Peraturan Daerah tersebut diterbitkan Peraturan Walikota Bandung Nomor 393 Tahun 2012 Tentang Tata Cara Pemungutan Bea Perolehan Hak Atas Tanah Dan Bangunan, yang telah diubah dengan Peraturan Walikota Bandung Nomor 308 Tahun 2013 Tentang Perubahan Atas Peraturan Walikota Bandung Nomor 393 Tahun 2012 Tentang Tata Cara Pemungutan Bea Perolehan Hak Atas Tanah Dan Bangunan.

Peraturan tersebut merupakan landasan hukum operasional dan teknis pelaksanaan pengenaan dan pemungutan BPHTB di Kota Bandung. Ditetapkan dalam Pasal 8 ayat (1) Perda Kota Bandung bahwa "saat terutangnya Bea Perolehan Hak 
Atas Tanah dan Bangunan ditetapkan untuk jual beli adalah sejak tanggal dibuat dan ditandatanganinya akta". Pejabat Pembuat Akta Tanah/Notaris hanya dapat menandatangani akta pemindahan Hak atas Tanah dan/atau Bangunan setelah Wajib Pajak menyerahkan bukti pembayaran pajak yang disebut Surat Setoran Pajak Daerah (SSPD), demikian menurut bunyi Pasal 9 ayat (1) Perda Kota Bandung.

Pembayaran pajak yang terutang harus dilakukan secara sekaligus atau lunas di Kas Daerah atau tempat lain yang ditunjuk oleh Walikota, demikian menurut Pasal 12 Perda Kota Bandung. Wajib Pajak, wajib membayar pajak yang terutang dengan tidak mendasarkan pada adanya Surat Ketetapan Pajak Daerah (SKPD) melainkan dilakukan dengan menggunakan Surat Setoran Pajak Daerah (SSPD) yang juga merupakan Surat Pemberitahuan Pajak Daerah (SPTPD). SSPD tersebut selanjutnya akan disampaikan kepada Walikota atau Pejabat yang ditunjuk sebagai bahan untuk dilakukan penelitian. Penelitian dimaksud merupakan serangkaian kegiatan yang dilakukan untuk menilai kelengkapan pengisian Surat Pemberitahuan Pajak Daerah dan lampiran-lampirannya termasuk penilaian tentang kebenaran penulisan dan penghitungannya.

Disebutkan pula dalam Perda Kota Bandung Pasal 13 ayat (1), bahwa dalam jangka waktu 5 (lima) tahun sesudah saat terutangnya pajak, Walikota dapat menerbitkan (i) Surat Ketetapan Pajak Daerah Kurang Bayar (SKPDKB) apabila berdasarkan hasil pemeriksaan atau keterangan lain, pajak yang terutang tidak atau kurang dibayar; dan (ii) Surat Ketetapan Pajak Daerah Kurang Bayar Tambahan (SKPDKBT) apabila ditemukan data baru dan/atau data yang semula belum terungkap yang menyebabkan penambahan jumlah pajakyang terutang. Surat Ketetapan Pajak Daerah Kurang Bayar dan/atau Surat Ketetapan Pajak Daerah Kurang Bayar Tambahan merupakan sarana penagihan, jika Wajib Pajak tidak memenuhi kewajibannya sebagaimana mestinya.

Pemungutan pajak BPHTB yang dilaksanakan oleh Satuan Kerja 
Perangkat Daerah masing-masing Pemerintah Kota/Kabupaten didasari oleh UU Nomor 28 Tahun 2009 beserta peraturan pelaksanaannya yang terdapat dalam Peraturan Pemerintah, Peraturan Daerah masing-masing Kota/Kabupaten merupakan dasar kewenangan Negara/Daerah dalam memungut pajak BPHTB. Diadakannya pajak dengan Undang-Undang telah memberikan legalitas bagi Negara/Daerah untuk memungut pajak, karena secara historis dalam praktek pemungutan pajak terdapat adagium di Inggris : "No taxation withourt representation" (tidak ada pajak tanpa persetujuan parlemen), sedangkan di Amerika dikenal ungkapan "Taxation without representation is robbery" (pajak tanpa persetujuan parlemen adalah perampokan).

Di Indonesia pengejawantahan ungkapan-ungkapan tersebut tertuang dalam Undang-Undang Dasar Republik Indonesia Tahun 1945 Pasal 23 A sebagai landasan konstitusional pemungutan pajak oleh Negara/Daerah dengan menyebutkan "pajak dan pungutan lain yang bersifat memaksa untuk keperluan negara diatur dengan undang-undang". Dengan demikian pemungutan pajak hanya boleh dilakukan oleh Negara/Daerah setelah ada peraturan perundangundangan yang dipakai sebagai dasar hukum penetapan dan pemungutan pajak. Asas ini dinamakan "kekuasaan undang-undang" (de heerschappij van de wet) (H.D. van Wijk/Willem Konijnenbelt, 1995 : 41). Pungutan pajak dengan didasari undang-undang telah melemahkan sifat paksaan pada pajak, karena Undang-Undang dibuat oleh Pemerintah bersama-sama dengan Dewan Perwakilan Rakyat (DPR) mencerminkan representasi rakyat, dengan kata lain sifat paksaan itu menjadi lemah dan hilang karena rakyat telah menyatakan persetujuannya melalui wakilwakilnya di DPR.

$$
\text { Undang-Undang semata }
$$
belumlah cukup bagi Negara/Daerah untuk melaksanakan pemungutan pajak, karena pajak dalam pemungutannya harus memperhatikan pula asas-asas hukum dalam pemungutan pajak. 
Asas-asas ini menjadi penting karena pengertian dan istilah "asas" menurut terminologi dalam bahasa Indonesia, adalah "dasar" yang artinya yaitu "sesuatu yang menjadi tumpuan berpikir atau berpendapat" (Departemen Pendidikan dan Kebudayaan, 2003 :70). Asas dalam pengertian hukum ialah apa yang menjadi dasar dari suatu norma atau kaidah. Istilah asingnya (Belanda) adalah beginsel. Kata beginsel berasal dari kata kerja beginnen, yaitu mengawali. Jadi asas adalah apa yang mengawali suatu kaidah atau awal suatu kaidah (Bachsan Mustafa, 1984 : 96). Di dalam bahasa Inggris istilah asas dikenal dengan sebutan Principle. Asas (principle) adalah sesuatu yang dapat dijadikan sebagai alas, sebagai dasar, sebagai tumpuan, sebagai pokok pangkal, sebagai fondamen, sebagai tempat untuk menyandarkan, untuk mengembalikan sesutu hal yang akan kita jelaskan (Mahadi, 1989 : 119).

Di dalam penyusunan UndangUndang Perpajakan asas hukum dijadikan landasan dan memberi pedoman kepada pembuat UndangUndang agar pemungutan pajak itu berhasil. Agar pemungutan pajak itu berhasil, maka harus dipenuhi syaratnya diantaranya syarat sebagaimana dikemukakan oleh Adam Smith yaitu (Rochmat Soemitro, 1990 : 15)convinience of payment. Asas convinience of paymentsejak tahun 1984 diterapkan di Indonesia dan menjiwai UndangUndang Pajak Penghasilan. Berdasarkan asas convinience of payment, untuk keberhasilan pemungutan pajak penghasilan (Rochmat Soemitro, 1990 : 26), yaitu "hendaknya pajak itu dipungut pada saat yang paling tepat bagi wajib pajak", dalam hal ini pajak dipungut pada saat sedekat mungkin dengan detik diterimanya penghasilan oleh wajib pajak. Dalam konteks penelitian ini, kiranya penerapan sistem pemungutan pajak penghasilan yang didasarkan pada asas convinience of payment, roh-nya daripada asas tersebut kiranya digunakan pada pemungutan pajak BPHTB melalui metode penafsiran hukum sistematis. Berdasarkan penafsiran sistematis, "hukum dilihat sebagai satu kesatuan, sebagai sistem peraturan, hukum tidak dilihat 
sebagai peraturan yang berdiri sendiri tetapi sebagai bagian dari satu sistem. Hubungan antara keseluruhan peraturan tidak semata-mata ditentukan oleh tempat peraturan itu terhadap satu sama lain tetapi oleh tujuan bersama atau asas-asas yang bersamaan yang mendasarkan pada peraturan-peraturan itu".

Persamaan tujuan yang ingin dicapai pada pemungutan Pajak Penghasilan (PPh) dengan pajak BPHTB, tidak lain adalah agar hasil pemungutan pajak dari wajib pajak dapat masuk secepat mungkin ke dalam Kas Negara/Daerah, sebab pajak sesuai dengan fungsinya untuk mengumpulkan uang sebanyakbanyaknya merupakan sumber penerimaan terbesar negara yang pada waktunya akan digunakan untuk membiayai pengeluaranpengeluaran negara/pemerintah (yang terdiri dari pengeluaran rutin dan pembangunan) bagi kepentingan masyarakat umum (Wirawan B. Ilyas, Richard Burton, 2003 : 10-11).

Kiranya untuk keberhasilan pemungutan pajak BPHTB, maka pemungutannya harus dilakukan pada saat yang tepat yaitu saat diperolehnya hak atas tanah oleh wajib pajak. Saat kapan sebagai saat diperolehnya hak atas tanah adalah saat ditandatanganinya Akta oleh PPAT. Legitimasi penandatanganan Akta oleh PPAT adalah ketika wajib dapat menunjukan bukti Surat Setoran Pajak Daerah. Dalam hal ini, penunaian kewajiban pajak terutang oleh wajib pajak mendahului perolehan haknya harus dilihat berdasarkan pada titik taut yang erat di antara Pasal 91 Ayat (1) yang berbunyi : "Pejabat Pembuat Akta Tanah/Notaris hanya dapat menandatangani akta pemindahan Hak atas Tanah dan/atau Bangunan setelah Wajib Pajak menyerahkan bukti pembayaran pajak", dan Pasal 90 Ayat (1) a, yang berbunyi : "Saat terutangnya pajak Bea Perolehan Hak atas Tanah dan/atau Bangunan ditetapkan untuk jual beli adalah sejak tanggal dibuat dan ditandatanganinya Akta". Titik taut dari kedua pasal dalam peraturan ini ditujukan untuk keberhasilan pemungutan pajak BPHTB, dan agar hasil pemungutan pajak yang dibayar oleh wajib pajak dapat secara cepat diterima oleh Kas Daerah pada saat 
diperolehnya hak atas tanah oleh wajib pajak (penerima hak atas tanah).

\section{Pengenaan}

kewajiban

pembayaran pajak kepada wajib pajak sebelum ditandatangainya Akta oleh PPAT mengindikasikan, pemungut pajak sejauh mungkin berupaya menghindarkan dari kemungkinan pengingkaran kewajiban pembayaran pajak oleh penerima hak baru. Hal ini seperti dikemukakan pada uraian terdahulu, bahwa pemindahan hak atas tanah melalui perbuatan hukum peralihan hak atas tanah yang dituangkan dalam Perjanjian Jual Beli yang dibuat oleh dan dihadapan PPAT,mengakibatkan beralihnya hak atas tanah dari satu pihak (penjual) kepada pihak lainnya (pembeli). Sejak saat itulah hak atas tanah beralih dari penjual kepada pembeli.

Dengan kata lain perolehan hak atas tanah oleh pembeli terjadi ketika ditandatanganinya Akta oleh PPAT.Akta PPAT tersebut menjadi dasar atau alas hak bagi penerima hak baru (pembeli) untuk mengklaim dirinya sebagai pemegang hak baru. Pemegang hak baru berhak mengajukan permohonan Balik Nama melalui proses pendaftaran tanah di Kantor Pertanahan.Pejabat Balik Nama akan melakukan pencoretan pada Sertifikatnya"nama pemilik semula"dan menggantinya dengan "nama pemilik baru". Sekalipun belum dilakukan Balik Nama di Kantor Pertanahan, "penerima hak baru" sudah memiliki kecakapan menurut hukum untuk mengenyam kenikmatan atas hak yang telah diperolehnya atau bahkan untuk mengalihkan hak-nya kepada pihak lain.

\section{Simpulan}

Ketentuan Pasal 91 Ayat (1) Undang-Undang Nomor 28 Tahun 2009 menimbulkan kerancuan dalam penerapannya, karena secara teoretik bertentangan dengan prinsip timbulnya utang pajak.Menurut ajaran materiil, timbulnya utang pajak adalah ketika terdapat alasan pengenaan pajak (taatbestand). Tanpa taatbestand, utang pajak belum timbul, namun bunyi Pasal 91 Ayat (1) menyatakan sebaliknya, yaitu utang pajak timbul tanpa dipenuhinya taatbestand. Penerapan 
Pasal 91 Ayat (1) dipedomani oleh asas hukum,"pajak dipungut pada saat yang tepat bagi wajib pajak", yaitu saat yang paling dekat dengan detik diperolehnya hak (atas tanah). Ini merupakan upaya fiskus untuk menghindari pengingkaran kewajiban pembayaran pajak BPHTB oleh penerima hak baru.

\section{Daftar Pustaka}

\section{Buku}

Bachsan Mustafa, Sistem Hukum Indonesia, Penerbit Remaja Karya C.V, Bandung, 1984.

Boedi Harsono, Hukum Agraria Indonesia Sejarah Pembentukan UndangUndang Pokok Agraria, Isi dan Pelaksanaannya, Penerbit Jambtan, Jakarta, 2003.

Bushar Muhammad, Asas-Asas Hukum Adat Suatu Pengantar, Penerbit Pradnya Paramita, Jakarta, 1994

Dewi Kania, Zainal Muttaqin, Hukum Pajak, Buku Ajar, Penerbit Kalam Media, Bandung, 2015.

H. Mustaqiem, Pajak Daerah Dalam Transisi Otonomi Daerah, FH UIIPress, Yogyakarta, 2008.

H.D. van Wijk/Willem Konijnenbelt, Hoofdstukken Adminiestratief
Uitgeverij Lemma B.V., Utrecht, 1995.

K. Wantjik Saleh, Hak Anda Atas Tanah, Penerbit Ghalia Indonesia, Jakarta, 1977.

R. Santoso Brotodihardjo, Pengantar Ilmu Hukum Pajak, Penerbit Refika Aditama, Bandung, 2003.

Rochmat Soemitro, Asas dan DasarDasar Perpajakan, Penerbit PT. Eresco, Bandung, 1990.

Asas-asas Hukum Perpajakan, Penerbit Binacipta, Jakarta, 1991

Mahadi, Falsafah Hukum, suatu Pengantar, PT Citra Aditya Bakti, 1989.

Subekti, Aneka Perjanjian, Penerbit Alumni, Bandung, 1982.

Soerjono Soekanto, Hukum Adat Indonesia, Penerbit PT Raja Grafindo Persada Cet.ke-6 November 2003, Jakarta.

Tulis S Meliala, Perpajakan Dalam Teori dan Praktek, Penerbit Vrama Widia Dharma, Bandung, 1991.

Wirawan B. Ilyas, Richard Burton, Hukum Pajak, Penerbit Salemba Empat, Jakarta, Edisi 3, 2003

\section{Jurnal}

Hatta Isnaini Wahyu Utomo dan Hendry Dwicahyo Wanda,Prinsip KehatiHatian Pejabat Pembuat Akta Tanah dalam Peralihan Tanah yang Belum Bersertifikat, Jurnal 
Hukum Ius Quia Iustum No. 3 Vol. 24 Juli 2017.

R. Murjiyanto dan Samun I., Menetapkan Pilihan Nilai Jual Obyek Pajak Bumi dan Bangungan sebagai Dasar Penghitungan Bea Perolehan Hak atas Tanah dan Bangunan, Jurnal Hukum Ius Quia Iustum No. 1 Vol. 23 Januari 2016.

\section{Kamus}

Departemen Pendidikan dan Kebudayaan, Kamus Besar Bahasa Indonesia, Edisi ke3, Penerbit Balai Pustaka, Jakarta, 2003.

\section{Peraturan Perundang-undangan}

Undang-Undang Dasar Republik Indonesia Tahun 1945

Kitab Undang-Undang Hukum Perdata.

Undang-Undang Nomor 5 Tahun 1960 tentang Peraturan Dasar Pokok-Pokok Agraria.

Undang-Undang Nomor 28 Tahun 2009 tentang Pajak Daerah dan Retribusi Daerah.

Peraturan Pemerintah Republik Indonesia Nomor 91 Tahun 2010 Tentang Jenis Pajak Daerah Yang Dipungut Berdasarkan Penetapan Kepala Daerah Atau Dibayar Sendiri Oleh Wajib Pajak.

Peraturan Pemerintah Republik Indonesia Nomor 37 Tahun 1998 Tentang Peraturan Jabatan Pejabat Pembuat Akta Tanah.
Peraturan Pemerintah Republik Indonesia Nomor 24 Tahun 1997 Tentang Pendaftaran Tanah.

Peraturan Menteri Agraria/Kepala Badan Pertanahan Nasional Nomor 3 Tahun 1997 tentang Ketentuan Pelaksanaan Peraturan Pemerintah Nomor 24 Tahun 1997 Tentang Pendaftaran Tanah.

Peraturan Daerah Kota Bandung Nomor 02 Tahun 2011 Tentang Bea Perolehan Hak Atas Tanah Dan Bangunan. 